\title{
Porcine luteinising hormone given at oestrus onset by intramuscular route does not advance ovulation in gilts
}

\author{
Hormônio luteinizante suíno aplicado no início do estro pela via \\ intramuscular não antecipa a ovulação em leitoas
}

\section{Rafael da Rosa Ulguim ${ }^{I}$ Pedro Ernesto Sbardella ${ }^{I}$ Diogo Luiz Fontana ${ }^{I}$ Julia Linck Moroni Luiza Pommerehn ${ }^{\mathrm{I}}$ Mari Lourdes Bernardi ${ }^{\mathrm{II}}$ Ivo Wentz ${ }^{\mathrm{I}}$ Fernando Pandolfo Bortolozzo ${ }^{\mathrm{I}^{*}}$}

\section{- NOTE -}

\section{ABSTRACT}

This study aimed to evaluate the use of porcine luteinising hormone ( $\mathrm{pLH}$ ) given at oestrus onset in gilts to synchronise ovulation. A total of 120 gilts (40/treatment) were assigned in three treatments: control - application of placebo by intramuscular (i.m.) route at oestrus onset; $p L H 2.5$ - application of $2.5 \mathrm{mg}$ of $\mathrm{pLH}$ by i.m. route at oestrus onset; pLH5 - application of $5 \mathrm{mg}$ of pLH by i.m. route at oestrus onset. On average, the interval onset of oestrus to ovulation did not differ $(P>0.05)$ among treatments (control - 28.7 $\pm 1.6 \mathrm{~h}$;

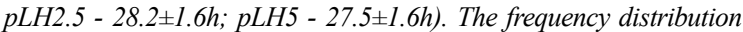
of gilts ovulated in different moments after oestrus detection was not affected $(P>0.05)$ by the treatment. In conclusion, the use of $2.5 \mathrm{mg}$ or $5 \mathrm{mg}$ of $\mathrm{pLH}$ given at oestrus onset in gilts by i.m. route does not advance and synchronises the interval onset of oestrus to ovulation.

Key words: ovulation induction, swine reproduction, reproductive biotechniques.

\section{RESUMO}

Este estudo teve como objetivo avaliar o uso do hormônio luteizante suíno ( $\mathrm{pLH}$ ) aplicado no início do estro em leitoas para sincronização da ovulação. Um total de 120 leitoas (40/tratamento) foram distribuidas em três tratamentos: controle aplicação de placebo por via intramuscular (i.m.) no início do estro; pLH2,5 - aplicação de 2,5mg de pLH por via i.m. no início do estro; pLH5 - aplicação de $5 \mathrm{mg}$ de pLH por via i.m. no início do estro. Em média, o intervalo início do estro e a ovulação não diferiu $(P>0,05)$

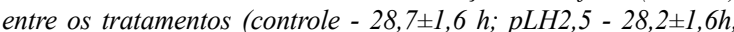
pLH5 - 27,5 1,6h). A distribuição de frequência de leitoas ovuladas em diferentes momentos após a detecção de estro não foi afetada pelos tratamentos $(P>0,05)$. Assim, o uso de 2,5mg ou $5 \mathrm{mg}$ de $\mathrm{pLH}$ aplicado no início do estro por via i.m. em leitoas não antecipa nem sincroniza o intervalo início do estro e a ovulação.

Palavras-chave: indução da ovulação, reprodução suína, biotécnicas reprodutivas.
Several hormonal protocols to synchronise ovulation are available for weaned sows (MARTINATBOTTÈ et al., 2010; ZAK et al., 2011; FONTANA et al., 2014). However, little information is available regarding synchronised ovulation in gilts. Usually the hormonal protocols for gilts include the use of progestogens to synchronise oestrus before the application of follicle growth and ovulation inductors (DEGEINSTEIN et al., 2008; MARTINAT-BOTTÈ et al., 2010). However, these protocols are laborious and expensive. Alternative protocols to induce ovulation using porcine luteinising hormone (pLH) at oestrus onset were proposed by ZAK et al. (2011) and FONTANA et al. (2014) for weaned sows. In this way, this study aimed to evaluate the use of pLH given at oestrus onset in gilts to advance ovulation.

The experiment was performed in a breeding herd (6,200 sows), located in Southern Brazil, Santa Catarina State. A total of 120 gilts Camborough $^{\circledR}$ (Agroceres PIC, Patos de Minas, MG, Brazil) were used. After arriving at the farm, gilts were housed in collective pens with 40 animals to perform oestrus induction once a day, using mature boars and physical contact. At first oestrus, gilts were weighed and those weighing at least $120 \mathrm{~kg}$ were moved to individual crates. Fence-line boar contact combined with the backpressure test was performed three times a day $(8 \mathrm{am}, 16 \mathrm{pm}, 12 \mathrm{pm})$ starting $17 \mathrm{~d}$ after the first oestrus and continuing until the end of oestrus. Gilts found to be in oestrus in different shifts of oestrus detection, were assigned into three

\footnotetext{
IFaculdade de Veterinária, Setor de Suínos, Universidade Federal do Rio Grande do Sul (UFRGS), Av. Bento Gonçalves, 9090, 91540-000, Porto Alegre, RS, Brasil. E-mail: fpbortol@ufrgs.br. "Corresponding author.
}

IIFaculdade de Agronomia, Departamento de Zootecnia, UFRGS, Porto Alegre, RS, Brasil. 
treatments: control $(n=40)$ - application of placebo at oestrus onset by intramuscular (i.m.) route; pLH2.5 $(\mathrm{n}=40)$ - application of $2.5 \mathrm{mg}$ of $\mathrm{pLH}$ (Lutropin- $\mathrm{V}^{\circledR}$ Bioniche Animal Health, Belleville, Ontario, Canada) by i.m. route at oestrus onset; pLH5 $(n=40)$ - application of $5 \mathrm{mg}$ of pLH by i.m. route at oestrus onset. Transcutaneous ultrasonography (TUS) of the ovaries was performed by a real-time ultrasonography using a convex linear transducer $5 \mathrm{MHz}\left(\right.$ Aloka $^{\circledR}$ SSD 500, Aloka Co. Ltd., Tokyo, Japan). TUS started at oestrus onset and was performed at $8 \mathrm{~h}$ intervals up to ovulation to determine the interval from onset of oestrus to ovulation (IOEO). Data were analysed using the Statistical Analysis System - SAS 9.1 (SAS, 2005). Results are expressed as LSmeans \pm SEM and percentages according to the variable type. The continuous variables such as oestrus duration and IOEO were analysed using the MIXED procedure with a comparison of means by the Tukey-Kramer test, including the week as a random variable. The frequency of IOEO at each period was analysed through Chi-squared test.

The frequency of oestrus expression was $48.3 \%$ in the morning, $26.7 \%$ in the afternoon and $25.0 \%$ at night. On average, the IOEO did not differ ( $\mathrm{P}>0.05)$ among treatments (control - 28.7 $\pm 1.6 \mathrm{~h}$; pLH2.5 - 28.2 $\pm 1.6 \mathrm{~h}$; pLH5 - 27.5 $\pm 1.6 \mathrm{~h}$ ). Differences in the oestrus duration among treatments were not observed $(\mathrm{P}>0.05$; Table 1$)$. The relative and cumulative frequency distribution of IOEO did not differ $(\mathrm{P}>0.05)$ among treatments in each moment of evaluation (Figure 1).

The use of $2.5 \mathrm{mg} \mathrm{pLH} 56 \mathrm{~h}$ after $600 \mathrm{UI}$ of eCG given at weaning in sows was proposed by VIANA et al. (2005), showing a reduction in the interval pLH application to ovulation $(40.0 \pm 5.9 \mathrm{~h})$ in relation to control sows using only eCG at weaning

Table 1 - Interval onset of oestrus to ovulation (h) and oestrus duration (h) of gilts submitted to application of porcine luteinising hormone $(\mathrm{pLH})$ at oestrus onset using different dosages.

\begin{tabular}{lccc}
\hline Treatment & $\mathrm{n}$ & IOEO & Oestrus duration \\
\hline Control & 40 & $28.7 \pm 1.6$ & $50.0 \pm 1.8$ \\
pLH2.5 & 40 & $28.2 \pm 1.6$ & $54.0 \pm 1.8$ \\
pLH5 & 40 & $27.5 \pm 1.6$ & $52.2 \pm 1.8$ \\
\hline
\end{tabular}

Control - application of placebo at oestrus onset; pLH2.5 - use of $2.5 \mathrm{mg}$ of pLH at oestrus onset; pLH5 - use of $5 \mathrm{mg}$ of pLH at oestrus onset.

IOEO - interval oestrus onset to ovulation.

Averages expressed as LSmeans $\pm \mathrm{SE}$.

No differences among treatments $(\mathrm{P}>0.05)$.
$(62.9 \pm 14.8 \mathrm{~h})$. However, in the same study, doses lower than $2.5 \mathrm{mg}$ (1.25 and $0.625 \mathrm{mg}$ of $\mathrm{pLH})$ were not effective to advance ovulation. Similarly, BENNETT-STEWARD et al. (2007) showed a reduction in the interval between $\mathrm{pLH}$ application and ovulation using $2.5 \mathrm{mg}(39.2 \pm 7.1 \mathrm{~h})$ or $5 \mathrm{mg}$ $(41.6 \pm 3.6 \mathrm{~h})$ of $\mathrm{pLH}$ injected by the i.m. route $80 \mathrm{~h}$ after 600UI of eCG compared to control sows where only placebo injection was used after eCG application (55.0 $\pm 11.1 \mathrm{~h})$.

Synchronisation of ovulation in gilts was suggested by DEGENSTEIN et al. (2008) using a protocol with altrenogest, cloprostenol, eCG and $5 \mathrm{mg}$ of pLH by i.m. route $80 \mathrm{~h}$ after eCG application. This study showed a reduction in the interval between pLH application and ovulation $(43.2 \pm 2.5 \mathrm{~h})$ in relation to gilts that received only placebo $80 \mathrm{~h}$ after eCG (59.5 $\pm 2.5 \mathrm{~h})$. Although the results cited above in weaned sows and gilts showed a positive effect of pLH after eCG on the advancement of ovulation, the observations in this study showed that the application of 2.5 or $5 \mathrm{mg}$ of pLH by the i.m. route at oestrous onset did not advance ovulation in gilts. This result corroborates those of FONTANA et al. (2014), who did not observe any advance in ovulation time when $5 \mathrm{mg}$ of $\mathrm{pLH}$ was given by the i.m. route at oestrus onset in weaned sows submitted to oestrus detection once a day. However, ULGUIM et al. (2014) showed that the use of $2.5 \mathrm{mg}$ of $\mathrm{pLH}$ by vulvar submucosal route at oestrous onset in pubertal gilts submitted to oestrus detection twice a day reduced the interval from pLH application to ovulation $(32.3 \pm 1.4 \mathrm{~h})$ compared to gilts with no ovulation induction at oestrous onset $(34.7 \pm 1.4 \mathrm{~h})$. In the same study, the application of $5 \mathrm{mg}$ of $\mathrm{pLH}$ by i.m. route did not affect the interval between $\mathrm{pLH}$ application and ovulation $(32.3 \pm 1.4 \mathrm{~h})$ in comparison to the use of $2.5 \mathrm{mg} \mathrm{pLH}$ by the vulvar submucosal route and control gilts.

According to ULGUIM et al. (2014), the frequency of sows ovulated up to $24 \mathrm{~h}$ after $5 \mathrm{mg}$ pLH by the i.m. route $(31.4 \%)$ did not differ compared to gilts that did not receive any $\mathrm{pLH}$ application $(25.5 \%)$. Considering that the onset of LH surge can start seven hours before oestrous detection in gilts submitted to hormonal induction with eCG and $\mathrm{pLH}$ (DEGENSTEIN et al., 2008) and that the natural LH surge in sows can start five hours before oestrus detection (SOEDE et al., 1994), the application of $\mathrm{pLH}$ at oestrous onset could be too late to advance ovulation. Studies that showed a reduction in the interval pLH application and ovulation did not observe any effect on oestrus duration (DEGENSTEIN et 

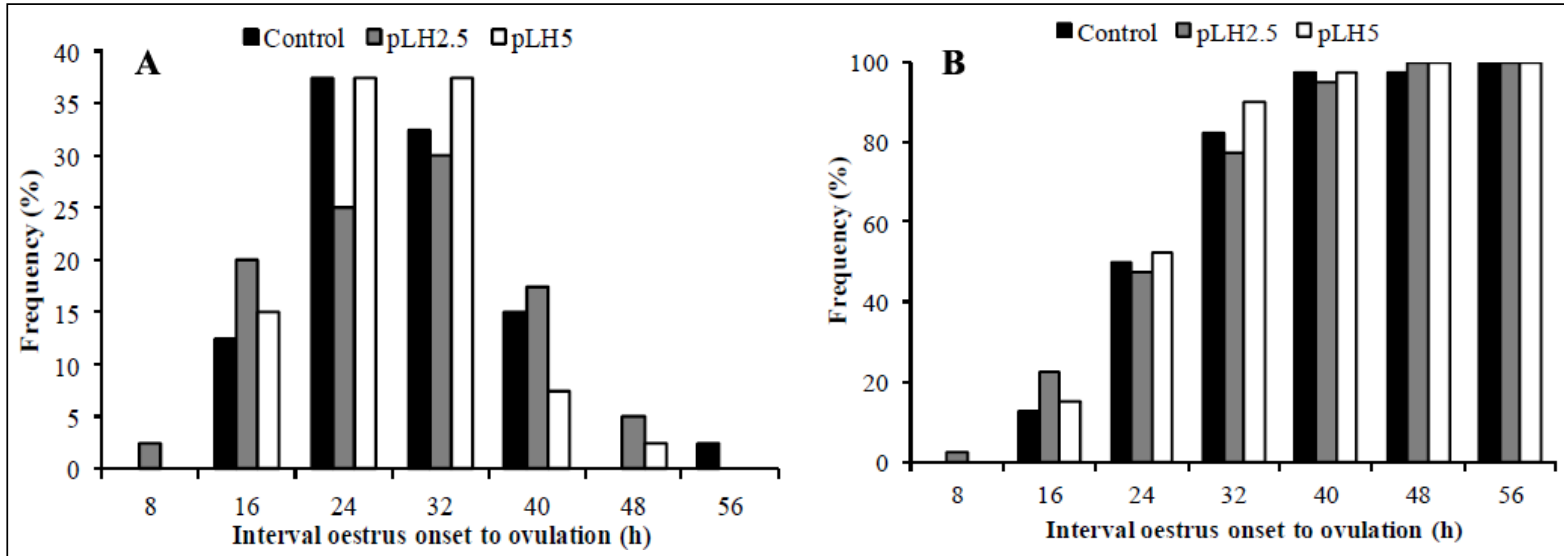

Figure 1 - Relative (A) and cumulative (B) frequency of the interval oestrus onset to ovulation in gilts submitted to application of different dosages of porcine luteinising hormone $(\mathrm{pLH})$ at oestrus onset.

Control - application of placebo at oestrus onset; pLH2.5 - use of $2.5 \mathrm{mg}$ of pLH at oestrus onset; pLH5 - use of $5 \mathrm{mg}$ of pLH at oestrus onset.

No differences among treatments in each period of evaluation $(\mathrm{P}>0.05)$.

al., 2008; ULGUIM et al., 2014), similar to results observed in this study. In conclusion, the use of $2.5 \mathrm{mg}$ or $5 \mathrm{mg}$ of $\mathrm{pLH}$ given at oestrus onset in gilts does not advance and synchronise the interval between the onset of oestrus and ovulation.

\section{ACKNOWLEDGEMENTS}

The authors would like to thanks Coordenação de Aperfeiçoamento de Pessoal de Nível Superior (CAPES) and Agroceres PIC by financial support and the Master Genética Animal for provide farm and animals.

\section{INSTITUTIONAL ANIMAL CARE AND USE COMMITTEE}

The project was approved by Institutional Animal Care of Universidade Federal do Rio Grande do Sul (UFRGS) under the protocol number 22979.

\section{REFERENCES}

BENNETT-STEWARD, K. et al. Ovulation induction protocol using equine chorionic gonadotropin and porcine luteinizing hormone in the weaned sow. J Swine Health Prod, v.15, n.4, p.194-197, 2007. Available from: < http://www.aasp.org/shap/issues/v15n4/v15n4p194. html>. Accessed: Nov. 30, 2014.

DEGENSTEIN, K.L. et al. Synchronization of ovulation in cyclic gilts with porcine luteinizing hormone $(\mathrm{pLH})$ and its effects on reproductive function. Theriogenology, v.70, p.1075-1085, 2008. Available from: <http://www.sciencedirect.com/science/article/pii/ S0093691X08003798>. Accessed: Nov. 30, 2014. doi:10.1016/j. theriogenology.2008.06.027.
FONTANA, D.L. et al. Fixed-time post-cervical artificial insemination in sows receiving porcine luteinising hormone at oestrus onset. Anim Reprod Sci, v.144, p.109-114, 2014. Available from: <http:// www.sciencedirect.com/science/article/pii/S0378432013003503>. Accessed: Nov. 30, 2014. doi:10.1016/j.anireprosci.2013.12.003.

MARTINAT-BOTTÉ, F. et al. Induction and synchronization of ovulations of nulliparous and multiparous sows with an injection of gonadotropin-releasing hormone agonist (Receptal). Theriogenology, v.73, p.332-342, 2010. Available from: <http:// www.sciencedirect.com/science/article/pii/S0093691X09004312>. Accessed:Nov. 30, 2014. doi:10.1016/j.theriogenology.2009.09.017.

SAS Institute: SAS User's Guide, Release 9.1.3. Cary, NC, 2005. $8621 \mathrm{p}$

SOEDE, N.M. et al. Periovulatory profiles of oestradiol LH and progesterone in relation to oestrus and embryo mortality in multiparous sows using transrectal ultrasonography to detect ovulation. J Reprod Fertil, v.101, p.633-641, 1994. Available from: $<$ http://www.reproductiononline.org/content/101/3/633.long>. Accessed: Nov. 30, 2014.

ULGUIM, R.R. et al. Use of porcine luteinising hormone at oestrous onset in a protocol for fixed-time artificial insemination in gilts. Reprod Dom Anim, v.49, p.756-760, 2014. Available from: $\quad<$ http://onlinelibrary.wiley.com/doi/10.1111/rda.12362/ full>. Accessed: Nov. 30, 2014. doi:10.1111/rda.12362.

VIANA, C.H.C. et al. Determination of the minimum porcine LH dose in synchronization of ovulation in sows. In: INTERNATIONAL CONGRESS OF PIG REPRODUCTION, 2005, Amsterdam, Netherlands. Proceedings... Amsterdam: ICPR2005. p. 150.

ZAK, L.J. et al. Benefits of fixed-time breeding protocols. In: AMERICAN ASSOCIATION OF SWINE VETERINARIANS, 2011, Phoenix, USA. Proceedings... Phoenix: AASV2011. p.197-200. 